\title{
Sosialisasi Cara Berinteraksi melalui Video dan Banner Sebagai Upaya Pencegahan COVID-19
}

\author{
Edi Widianto1, Fithroh Nafa Dzillah², Silvi Ayu Dewi Mashito ${ }^{3}$ \\ ${ }^{1}$ Pendidikan Luar Sekolah, Fakultas Ilmu Pendidikan, Universitas Negeri Malang, Jalan Semarang No 5, \\ Malang, Jawa Timur, 65145, Indonesia, \\ 2Pendidikan Matematika, Fakultas Matematika dan Ilmu Pengetahuan Alam, Universitas Negeri Malang, \\ Jalan Semarang No 5, Malang, Jawa Timur, 65145, Indonesia \\ ${ }^{3}$ Pendidikan Fisika, Fakultas Matematika dan Ilmu Pengetahuan Alam, Universitas Negeri Malang, Jalan \\ Semarang No 5, Malang, Jawa Timur, 65145, Indonesia \\ e-mail: edi.widianto.fip@um.ac.id ${ }^{1}$, fithroh.nafa.17013116@students.um.ac.id ${ }^{2}$ \\ dewimashito.1703216@students.um.ac.id ${ }^{3}$
}

\begin{abstract}
The World Health Organization (WHO) has declared the COVID-19 outbreak as a pandemic since March 11, 2020 after the corona virus spread to 114 countries, including Indonesia. This is the aim of the Malang State University Community Service program for now, which is to participate in socializing how to interact during a pandemic in an effort to prevent the spread of COVID-19. The theme of the program is the socialization of ways to interact through videos and banners as an effort to prevent COVID-19, in Urek-urek Village, Gondanglegi District, Malang Regency. In accordance with the theme, the method used was education by using banner and video media which contained guidelines for interaction during the pandemic. This method was chosen because it is a form of social distancing because of this pandemic in Malang and surrounding areas. Banners are placed in front of the village, while the video is uploaded on the YouTube digital platform. Through this program, it is hoped that the people of Urek-urek Village, Gondanglegi District, Malang Regency can always maintain cleanliness during the current COVID-19 pandemic.
\end{abstract}

Keywords: Sosialization; Interaction; COVID-19; Video; Banner

\section{Abstrak}

Organisasi Kesehatan Dunia (WHO) telah menyatakan wabah COVID-19 sebagai pandemi sejak 11 Maret 2020 setelah virus corona tersebut menyebar ke 114 negara, termasuk Indonesia. Hal ini menjadi tujuan program KKN Universitas Negeri Malang untuk saat ini, yaitu ikut serta berpartisipasi dalam mensosialisasikan cara berinteraksi selama pandemi sebagai upaya mencegah penyebaran COVID-19. Tema dari program KKN ini yaitu sosialisasi cara berinteraksi melalui video dan banner sebagai upaya pencegahan COVID-19, di Desa Urek-urek, Kecamatan Gondanglegi, Kabupaten Malang. Sesuai dengan temanya, maka metode yang digunakan adalah edukasi dengan menggunakan media banner dan video yang berisi panduan interaksi selama pandemi. Metode ini dipilih karena sebagai wujud social distancing sebab pandemi ini di Wilayah Malang dan sekitarnya. Banner dipasang di depan desa, sedangkan video diuanggah di platform digital youtube. Melalui program ini, diharapkan masyarakat Desa Urek-urek, Kecamatan Gondanglegi, Kabupaten Malang dapat senantiasa menjaga kebersihan selama pandemi COVID-19 saat ini.

Kata kunci: Sosialisasi; Interaksi; COVID-19; Video; Banner

\section{PENDAHULUAN}

Wabah Covid-19 menghantam secara tiba-tiba ibarat serangan terorisme bahkan lebih dahsyat (Wardhana, 2020). Organisasi Kesehatan Dunia (WHO) secara sah telah memutuskan wabah virus corona atau Covid-19 menjadi pandemi pada 11 Maret 2020 setelah virus tersebut menyebar sedikitnya ke 114 negara (Sebayang, 2020). Pandemi merupakan wabah penyakit yang sedang terjadi pada wilayah yang luas dan memicu mudah tersebarnya infeksi dari satu orang ke orang lainnya di seluruh circle, mengutip the guardian oleh (Nugroho, 2020). WHO menyatakan bahwa ini adalah pandemi pertama yang disebabkan oleh novel coronavirus. Penyakit yang diakibatkan oleh novel coronavirus yang awal mula teridentifikasi di Wuhan, salah satu kota besar di Cina. Penyakit ini diberi nama coronavirus disease 2019 (COVID-19) - 'CO' singkatan untuk corona, 'VI' untuk virus, dan 'D' untuk disease (penyakit). Virus COVID-19 juga dikaitkan 
dengan kelompok virus yang juga sama dengan Severe Acute Respiratory Syndrome (SARS) serta beberapa jenis penyakit flu biasa (UNICEF, 2020).

Indikasi bagi penderita COVID-19 kebanyakan adalah demam, batuk kering, kekeruhan ground-glass bilateral pada CT scan dada, dan kesulitan bernapas (Chen et al., 2020), (Huang et al., 2020). Namun, beberapa pasien dengan infeksi COVID-19 memiliki tanda gejala saluran pernapasan atas yang menonjol (misalnya bersin atau sakit tenggorokan)(Huang et al., 2020). Penyakit ini dapat berujung pada pneumonia (Hui, 2020).

WHO mengatakan bahwa virus yang mengakibatkan COVID-19 ini dapat meluas utamanya dari satu orang ke orang lainnya melalui percikan-percikan yang biasanya dari hidung dan mulut sesorang, atau biasa disebut dengan droplet. Droplet ini biasanya keluar saat orang yang mengidap COVID-19 sedang batuk, berbicara, dan juga bersin (Organisasi Kesehatan Dunia (WHO), 2020). Orang-orang yang mengalami COVID-19 mempunyai berbagai macam gejala, dimulai dari gejala ringan sampai gejala berat. Gejala ini biasanya muncul 2-14 hari setelah sesorang terinfeksi virus corona (CDC, 2020), (Lai et al., 2020). Namun, rata-rata periode inkubasi COVID-19 adalah 5 hari(Velavan \& Meyer, 2020).

WHO menyarankan cara yang dapat ditempuh seseorang untuk melindungi dirinya serta mencegah penyebaran COVID-19 adalah dengan melakukan kebiasaan mencuci tangan dengan air dan sabun sesuai tata cata yang benar, menggunakan cairan antiseptik ketika berada di luar rumah agar praktis, selalu menjaga jarak dengan orang lain minimal 1 meter, serta menghindari segala bentuk keramaian. Selain itu juga disarankan menjalankan etika batuk dan bersin, yaitu menutup area mulut serta hidung dengan tisu atau siku (World Health Organization, 2020).

Oleh karena berbahayanya pandemi COVID-19 ini dan tergolong virus baru, sehingga banyak masyarakat yang masih kebingungan mengenai virus ini serta bagaimana cara pencegahan agar virus ini tidak semakin mudah menyebar. Maka mahasiswa Kuliah Kerja Nyata (KKN) Desa Urek-urek tergerak untuk ikut serta dalam mensosialisasikan dan mengedukasi masyarakat Desa Urek-urek mengenai cara berinteraksi selama pandemi COVID-19. Media edukasi yang dapat digunakan untuk penyuluhan atau sosialisasi kesehatan antara lain yaitu media visual, audio dan audio visual. Media audiovisual atau video merupakan salah satu media yang menyuguhkan informasi atau pesan secara audio dan visual (Fresia, 2017). Biasanya sosialisasi atau penyuluhan dilakukan dengan cara ceramah, namun untuk menghindari keramaian saat kegiatan sosialisasi berlangsung, serta banyak penelitian yang menyebutkan bahwa media edukasi audio visual atau video sangat bagus digunakan, maka mahasiswa KKN Desa Urek-urek berinisiatif untuk mengemasnya dalam banner dan video panduan interaksi selama pandemi COVID-19.

\section{METODE}

Program pengabdian masyarakat melalui kegiatan KKN yang dilakukan adalah sosialisasi cara berinteraksi selama pandemi COVID-19. Metode yang digunakan pada sosialisasi ini adalah edukasi kepada masyarakat melalui video dan banner mengenai panduan interaksi selama pandemi, dalam upaya mencegah penyebaran COVID-19. Metode ini dipilih karena wujud kepatuhan kita sebagai warga negara terhadap anjuran pemerintah, yang dikenal dengan himbauan pembatasan sosial berskala besar (PSBB) di banyak wilayah di Indonesia, khususnya Malang. Selain itu, metode ini juga dipilih sebagai bentuk rasa cinta kita terhadap dunia, sebagaimana yang telah dianjurkan oleh WHO mengenai aturan social distancing.

Tahapan yang ditempuh untuk program sosialisasi ini memuat tiga tahap, yaitu: adalah perencanaan, pelaksanaan, dan refleksi (review hasil). Adapaun rincian langkah untuk tiap-tiap tahapan antara lain sebagai berikut: 1) Tahap perencanaan yang meliputi, penentuan bentuk sosialisasi yang tepat dilakukan pada masa pandemi dan social distancing saat ini, mitigasi keadaan yaitu melakukan upaya untuk mengurangi dampak dari keadaan pandemi yang sedang terjadi, penyiapan sumber daya untuk menyelesaikan program sosialisasi ini, pembuatan banner 
yaitu dengan menentukan konsep banner, mendesain banner menggunakan aplikasi di laptop, dan mencetak banner, serta pembuatan video yaitu dengan menentukan konsep video, mendesain dan membuat karakter animasi menggunakan aplikasi di laptop, menyusun naskah, rekaman suara untuk karakter, dan edit finishing video secara keseluruhan. 2) Tahap pelaksanaan, yang meliputi pemasangan banner di depan Desa Urek-urek, sebagai bentuk pengarahan satu arah kepada masyarakat mengenai isi banner dan pengunggahan video di platform digital youtube milik kelompok KKN sebagai bentuk pengarahan satu arah juga kepada masyarakat mengenai isi video. 3) Tahap refleksi yang dapat dilihat dari antusiasnya masyarakat dalam menerima banner yang dipasang di depan desa dan video yang dipublikasikan melalui platform digital youtube, serta dampak positif yang diperoleh.

Tahapan di atas tentunya dilakukan secara sistematis. Untuk lebih mudah memahaminya, akan dibentuk dalam bagan seperti pada gambar 1 .

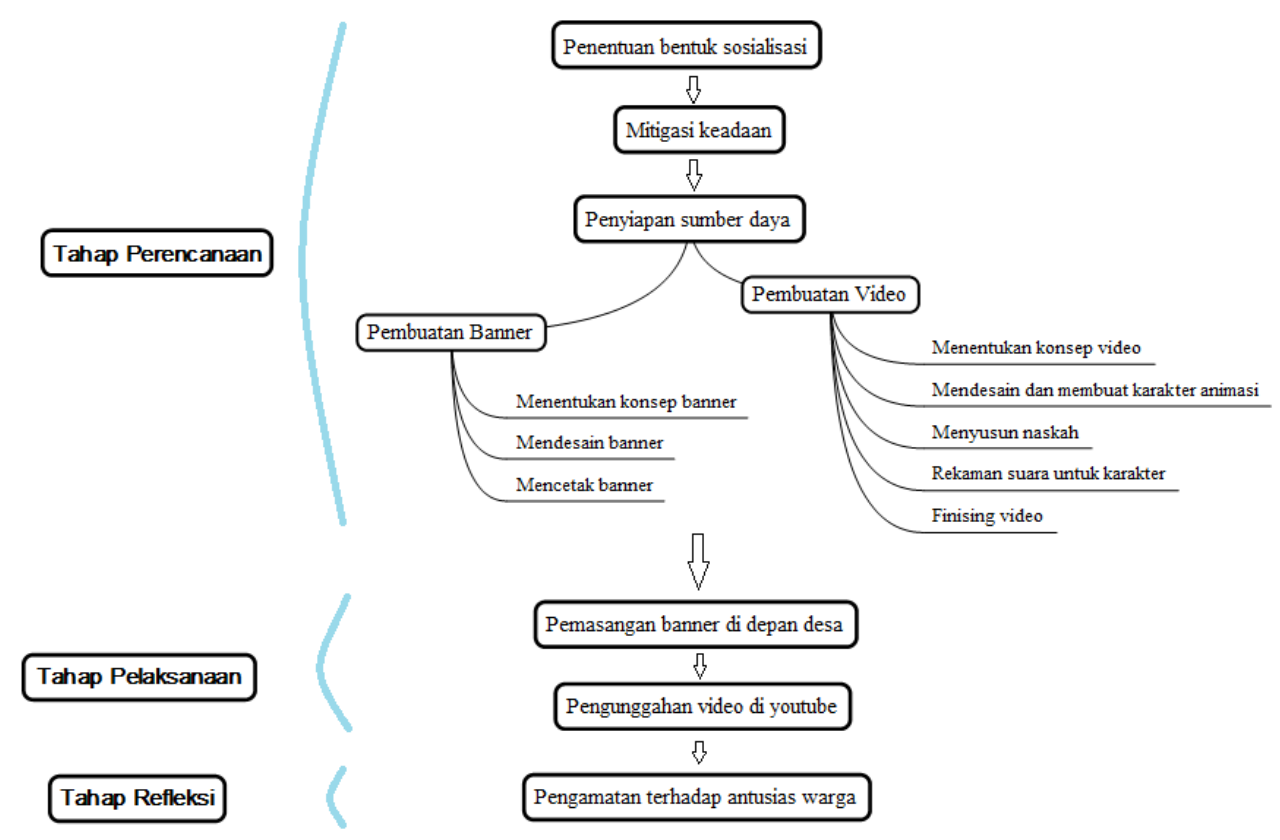

Gambar 1. Tahapan yang dilakukan dalam program sosialisasi

\section{HASIL DAN PEMBAHASAN}

Program KKN ini diadakan di Desa Urek-urek, Kecamatan Gondanglegi, Kabupaten Malang, sekitar $26 \mathrm{~km}$ dari Universitas Negeri Malang. Kegiatan diadakan pada tanggal $29 \mathrm{Mei}-7$ Juli 2020. Diketahui dari perangkat desa dan survei yang dilakukan anggota kelompok KKN, desa ini masih kurang peduli pada pandemi COVID-19 yang sedang terjadi. Padahal kebersihan merupakan faktor penting dalam pencegahan COVID-19. Sehingga adanya program sosialisasi melalui KKN ini ditargetkan mampu memberikan dampak positif sebagai salah satu solusi pada masalah kebersihan yang menjadi kunci penting dalam pencegahan COVID-19.

Berdasarkan pertimbangan di atas, maka bentuk sosialisasi yang dilakukan adalah dengan memberikan edukasi, atau bisa disebut pesan, kepada masyarakat tentang pentingnya menjaga cara berinteraksi terhadap sesama pada saat pandemi seperti sekarang ini melalui banner dan video. Dengan seperti ini, keramaian dapat dihindari dan sebagai wujud social distancing saat sedang diberlakukan PSBB di beberapa wilayah di negara ini, khususnya wilayah Malang yang merupakan lokasi kita melakukan program pengabdian ini. 
Melihat kondisi saat ini yang demikian, maka untuk merealisasikan pembuatan banner dan video dengan maksimal pada saat diberlakukan social distancing semua tahapan pelaksanaan sosialisasi dilakukan dengan membagi job dan dilakukan di rumah masing-masing. Koordinasi antar sesama tim juga dilakukan dilakukan secara daring.

Pada banner dan video, selain isi yang disampaikan di dalamnya sama, dipilih juga konsep desain yang sama. Mulai dari dasar warna yang sama, yaitu warna dasar biru sesuai dengan tema dan nuansa KKN yang selalu berseragam warna biru. Kemudian dari segi desain isi juga diberi gmabar animasi agar lebih bisa menarik perhatian masyarakat yang melihatnya. Jika masyarakat sudah tertarik melihatnya, maka akan dengan mudah masyarakat untuk mengaplikasikannya dalam kehidupan sehari-hari.

Meskipun tema yang diangkat sama dan keduanya terdapat gambar animasinya, namun gambar animasi yang digunakan untuk banner dan video berbeda. Gambar yang digunakan pada banner hanya sebatas simbol dari pesan yang disampaikan, seperti pada gambar 2 . Antara satu gambar dengan gambar lainnya juga tidak dalam satu tema. Terdapat gambar yang semacam animasi kartun, ada juga gambar yang seperti siluet saja. Meskipun tidak dalam satu tema model gambar yang dipilih, namun masing-masing gambar tetap mengandung makna dari masingmasing pesan yang ingin disampaikan.

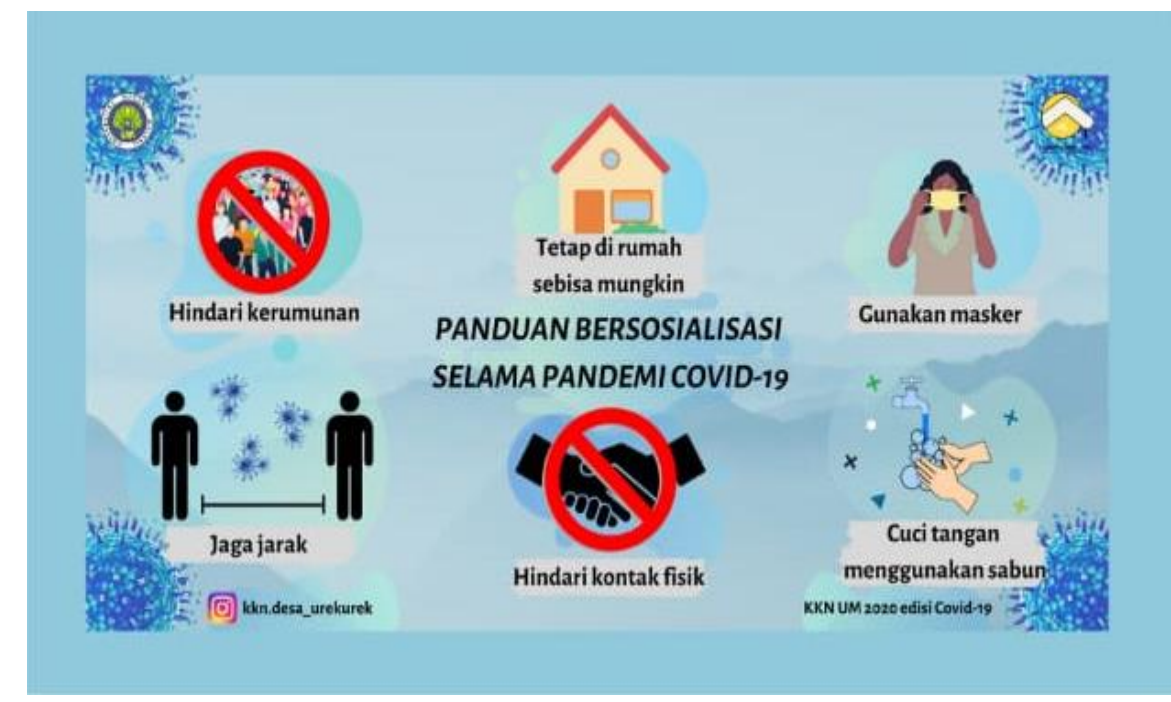

Gambar 2. Tampilan Banner

Sedangkan pada video, gambar animasi yang digunakan lebih terkonsep, yaitu menggunakan animasi karakter yang didesain senada untuk setiap poin-poin pada isi videonya, seperti pada yang terangkum pada gambar 11.

Selain itu, meskipun tema yang dipilih adalah sama-sama tentang cara berinteraksi dengan sesama sebagai upaya pencegahan penyebaran COVID-19, namun susunan judul yang digunakan berbeda tapi tetap memiliki makna yang sama. Untuk banner, judul nya adalah "Panduan Bersosialisasi Selama Pandemi COVID-19", seperti pada gambar 2. Sedangkan untuk video, judul yang digunakan adalah "Bersosialisasi Di Masa Pandemi", sebagaimana pada gambar 3. 


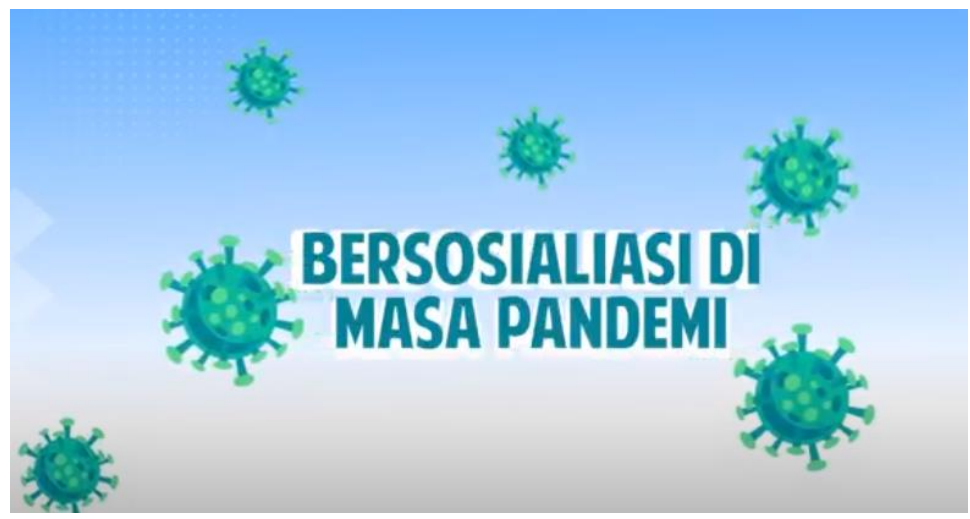

Gambar 3. Tampilan Awal Video

Setelah judul, pada video juga ditampilkan karakter-karakter animasi yang menyimbolkan mahasiswa KKN Universitas Negeri Malang untuk menarik perhatian masyarakat yang menyaksikannya dan juga agar masyarakat selalu teringat kepada mahasiswa KKN Universitas Negeri Malang, sebagaimana pada gambar 4.

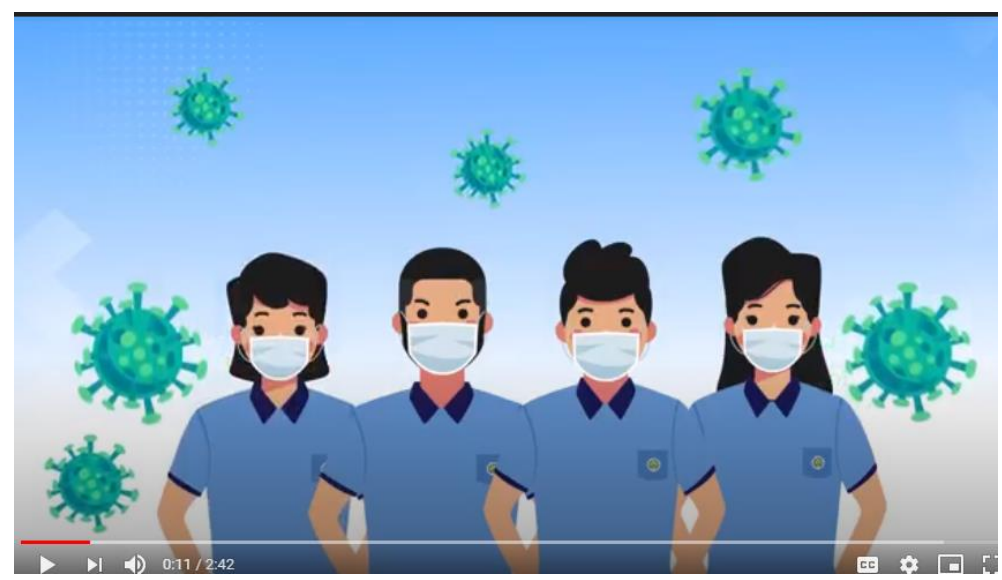

Gambar 4. Karakter Animasi Pada Video

Banner dan juga video sama-sama memuat 6 poin. Keenam poin tersebut antara lain: tetap di rumah, hindari kerumunan, jaga jarak minimal satu meter, hindari kontak fisik, cuci tangan dengan sabun, dan gunakan masker, seperti pada gambar 1 untuk banner dan yang terangkum pada akhir video pada gambar 11. Rekaman suara juga dibuat untuk mengisi kelengkapan unsur video.

Untuk banner, tidak memakan waktu yang terlalu lama untu mentyelesaikannya. Setelah konsep matang dan desain selesai, banner pun langsung dicetak. Sedangkan untuk video cukup memakan waktu yang lama karena perlu ketelitian dan ketekunan dalam membuatnya. Video memiliki durasi 2 menit 43 detik. Video juga memuat 6 poin yang sama dengan banner yang disertai karakter animasi untuk menarik antusias warga. Keenam poin ini ditampilkan satu per satu sebelum akhirnya dirangkum secara keseluruhan di akhir video.

Poin pertama berisi tentang himbauan agar warga tetap berada di rumah, seperti gambar 5. Poin ini penting disampaikan karena jika seseorang keluar rumah, maka kemungkinan akan bertemu atau berpapasan dengan banyak orang, yang mana seseorang tersebut tidak mengetahui apakah orang yang ditemuinya di luar rumah itu aman atau terbebas dari virus corona atau tidak. 


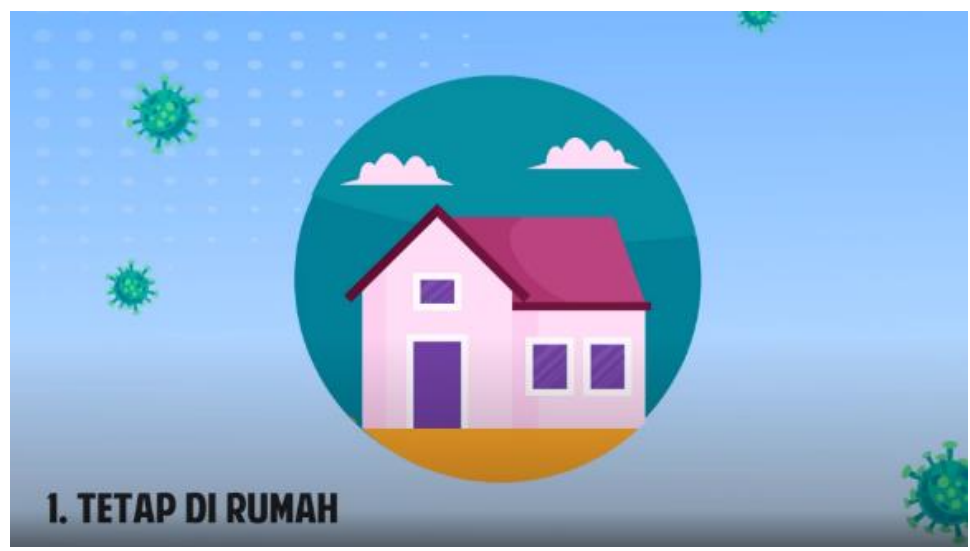

Gambar 5. Tampilan Pesan Untuk Tetap Di Rumah

Poin kedua yaitu himbauan untuk menghindari keramaian, seperti gambar 6. Maksud dari poin ini hampir mirip dengan poin sebelumnya. Namun yang menjadikan poin ini penting untuk disampaikan juga adalah, meskipun seseorang berada di dalam rumah, tapi di dalam rumah tersebut banyak orang yang dari luar rumah, maka itu juga berbahaya dan mesti dihindari. Contoh lebih jelasnya adalah, dalam masa pandemi seperti ini dilarang sementara untuk mengadakan acara walimah yang mengumpulkan banyak orang, meskipun acaranya di dalam rumah.

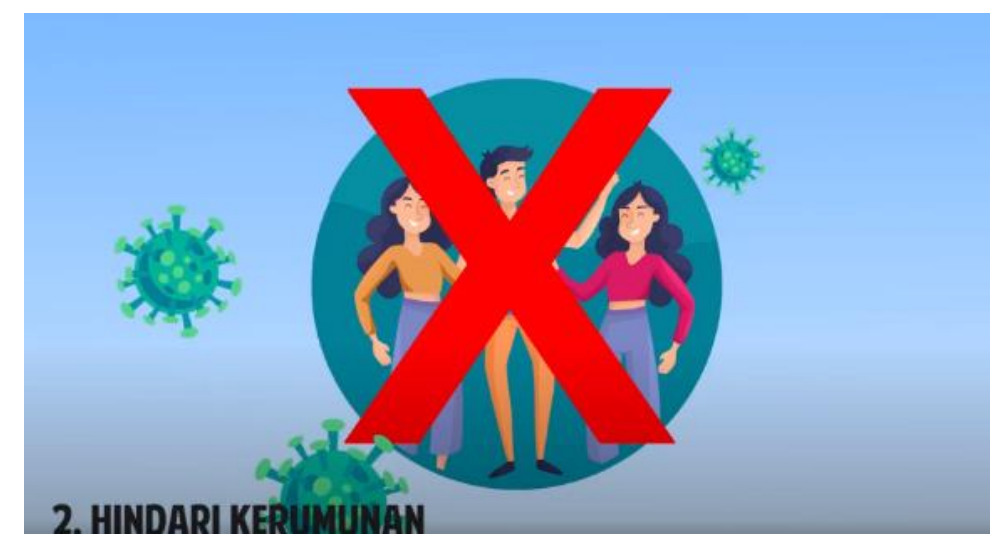

Gambar 6. Tampilan Pesan Untuk Selalu Menghindari Keramaian

Poin ketiga yaitu himbauan untuk selalu menjaga jarak anatar orang minimal satu meter, seperti gambar 7. Jika terpaksa harus bekerja keluar rumah, maka seseorang wajib menjaga jarak antar sesama. Semua ini dilakukan dengan kesadaran diri sendiri. Oleh karena itu, sementara hindari tempat-tempat yang kemungkinan terdapat banyak orang, contohnya supermarket. 


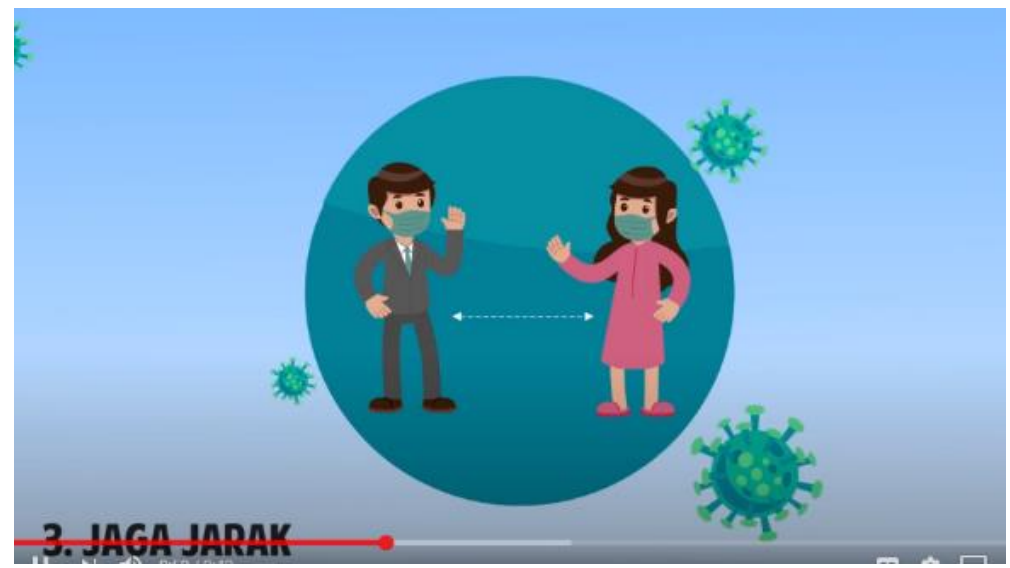

Gambar 7. Tampilan Pesan Untuk Selalu Menjaga Jarak

Poin keempat yaitu himbauan untuk menghindari kontak fisik dengan sesorang, seperti gambar 8. Selain menjaga jarak, tentunya kontak fisik juga dilarang. Contohnya adalah, semestara jabat tangan dilarang selama masa seperti ini. Sebagai gantinya adalah bisa dengan menundukkan kepala atau salam tradisional.

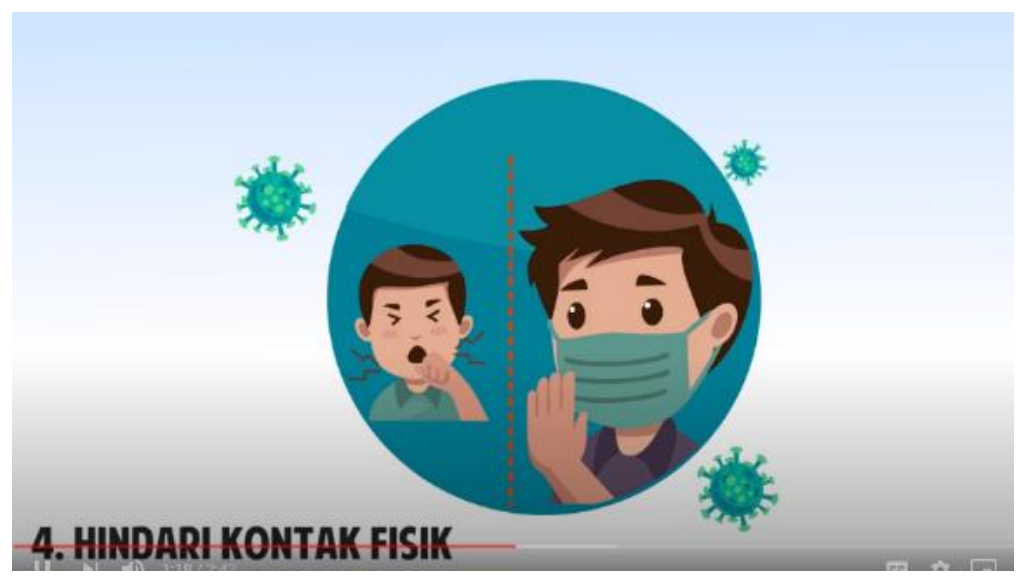

Gambar 8. Tampilan Pesan Untuk Senantiasa Menghindari Kontak Fisik

Poin kelima yaitu himbauan untuk selalu mencuci tangan setelah memegang sesuatu, seperti gambar 9. Menhindari kontak fisik dengan sesama tidak cukup untuk memastikan tangan sesorang bersih. Karena bisa jadi barang yang dipegang seseorang juga telah dipegang oleh orang lain. Ini artinya, kuman atau virus bisa menyebar tidak langsung melalui tangan ke tangan, tapi ada perantara suatu barang. 


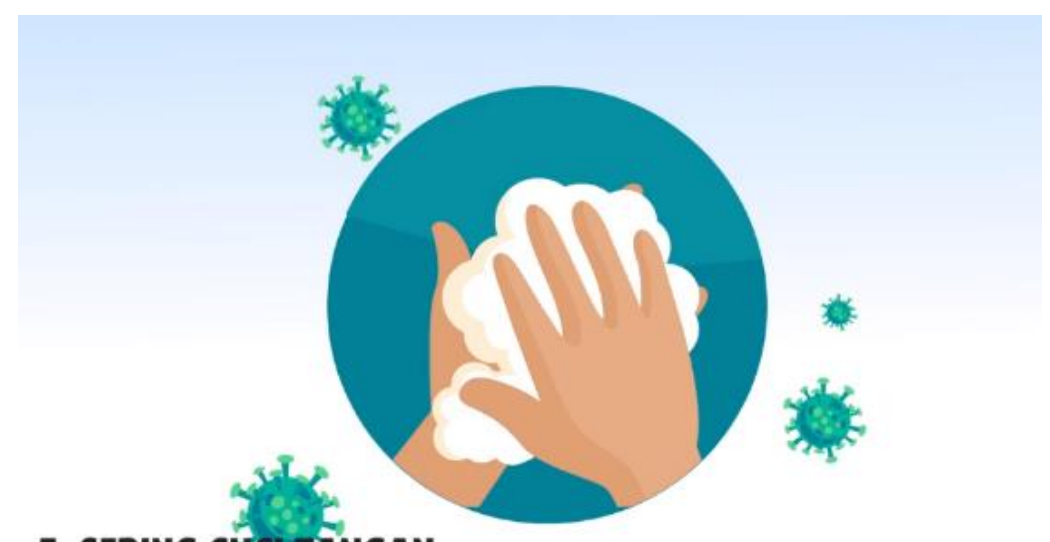

\section{SERING CUUCITANGAN}

Gambar 9. Tampilan Pesan Untuk Selalu Mencuci Tangan

Poin terakhir berisi himbauan untuk selalu memakai masker jika terpaksa keluar rumah, seperti gambar 10. Meskipun tidak sedang sakit, semua orang wajib menggunkan masker. Hal ini dilakukan untuk berjaga-jaga kalau ada orang sakit tapi tidak menggunakan masker. Dengan menggunkan masker, maka droplet-droplet tidak akan menyebar ke udara dan menempel ke orang lain.

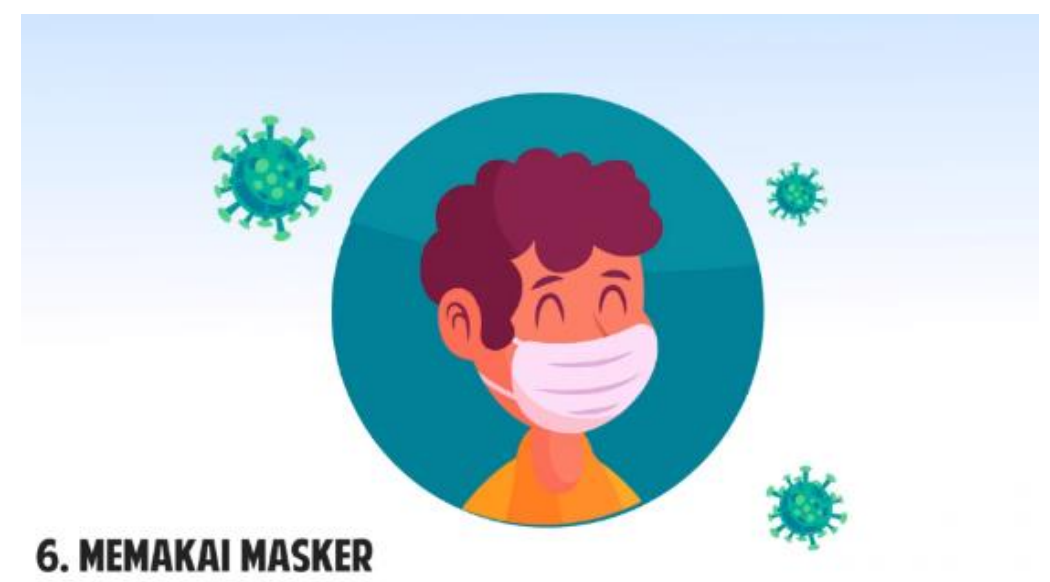

Gambar 10. Tampilan Pesan Untuk Selalu Memakai Masker

Di akhir video ditampilkan rangkuman keenam poin cara berinteraksi selama pandemi, seperti gambar 11. Setelah semua poin dipaparkan dan dijelaskan satu per satu, maka di akhir video, semua poin disimpulkan lagi di akhir. Hal ini dilakukan untuk menekankan kembali inti dari maksud video inim agar selalu teringat di semua yang menyaksikannya. 


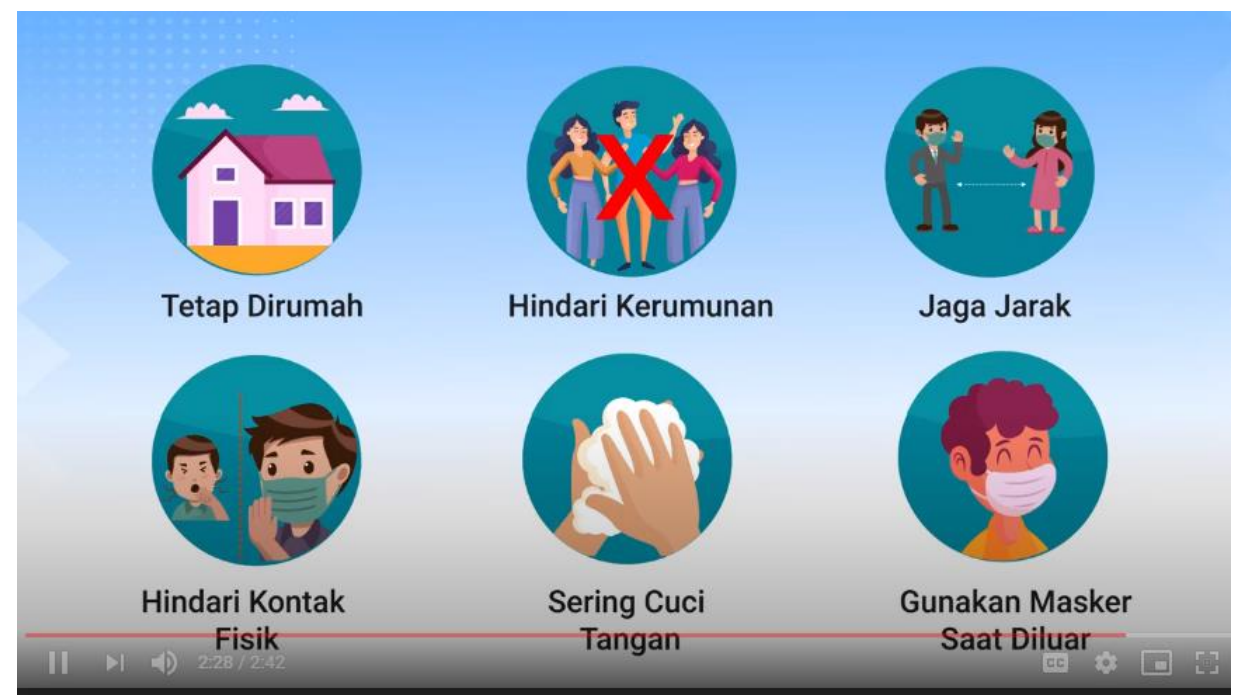

Gambar 11. Tampilan Rangkuman Pada Akhir Video

Setelah banner dicetak, banner di pasang di depan Desa Urek-urek, Kecamatan Gondanglegi, Kabupaten Malang. Perwakilan dari kelompok KKN yang bertugas di lapangan memasang banner ini dengan bantuan arahan dari kepala desa. Melalui banner ini, sosialisasi berlangsung. Setiap memasuki desa, warga melihat banner itu dan secara tidak langsung pesan atau himbauan dari kelompok KKN tersampaikan ke warga desa Urek-urek.

Sedangkan video diunggah di platform digital youtube agar semua warga desa, bahkan orang-orang selain warga desa. Melalui video ini, semua kalangan dapat melihat pesan atau himbauan ini. Mulai dari orang tua yang tidak dapat keluar rumah untuk melihat banner, sampai dengan anak-anak yang kurang tertarik dengan visual saja. Dengan ditontonnya video ini di youtube, maka secara tak langsung juga sosialisasi ini tersampaikan sesuai sasaran, bahkan mampu menjangkau lebih luas.

Pelaksanaan program sosialisasi ini bekerjasama dengan kepala desa dan perangkat Desa Urek-urek, Kecamatan Gondanglegi, Kabepaten Malang, agar dapat tercapai dengan maksimal. Atas izin pihak desa, akhirnya kelompok KKN Universitas Negeri Malang dapat merealisasikan program sosialisasi ini. Pihak desa juga membantu mengarahkan pemasangan banner panduan berinteraksi selama COVID-19 di depam desa. Dengan diletakkannya banner di depan desa, maka semua masyarakat desa dapat menjangkaunya karena letaknya yang straegis. Saat keluar masuk desa, pandangan masyarakat tertuju pada pesan singkat di banner ini. Sehingga pesan ini akan selalu diingat dan dapat diimplementasikan dalam kehidupan sehari-hari. Adapun dengan diunggahnya video di platform digital youtube, maka harapannya semua orang dapat mengaksesnya, terutama masyarakat Desa Urek-urek, Kecamtan Gondanglegi, Kabupaten Malang.

Dalam rangka ikut berkontribusi dalam kinerja gugus tugas percepatan penanganan dan menekan angka positif pasien Covid-19, video atau audio visual dipilih sebagai salah satu cara untuk mengedukasi masyarakat dalam berinteraksi saat pandemi seperti sekarang. Media audio visual atau video dipilih karena menurut banyak penelitian salah satunya yaitu menurut (Meidiana, Simbolon, \& Wahyudi, 2018) media audio visual selain menyajikan cara efektif dengan waktu yang cukup singkat, tetapi informasi atau pesan yang diterima juga akan lebih bertahan lama dan nyaman bersemayam dalam ingatan. Selain itu juga mampu mempermudah seseorang dalam menyalurkan ataupun menampung pesan dan informasi dan juga dapat meminimalisir salah pengartian. Audiovisual atau biasa kita sebut video memberikan dampak besar pada perubahan tingkah atau perilaku masyarakat, utamanyaa dalam aspek informasi dan persuasi (Sekti, Fayasari, Binawan, \& Timur, 2019). 
Pemilihan tema sosialisai cara berinteraksi selama pandemi COVID-19 ini sangat relevan dengan keaadan dunia saat ini, khususnya Indonesia. Dalam masa pandemi seperti ini, sangat penting bagi semua untuk senantiasa menjaga kebersihana agar tidak mudah terinfeksi virus corona, sebagaimana yang disampaikan oleh WHO (World Health Organization, 2020). Dengan demikian, maka isi pesan yang termuat dalam banner dan video ini antara lain sebagai berikut: 1) Himbauan untuk tetap berada di rumah. Selama pandemi, masyarakat dihimbau agar selalu berada di rumah masing-masing jika tak ada keperluan atau hal penting yang mendesak, seperti: membeli keperluan makanan, ke rumah sakit, dll. Di masa pandemi ini, tetap berada di dalam rumah adalah cara yang paling efektif untuk saat ini. 2) Himbauan agar selalu menghindari kerumunan. Jika ada keperluan yang mendesak yang mengharuskan untuk keluar rumah, hendaknya sebisa mungkin kita menghindari kegiatan yang melibatkan banyak orang. Secara berkerumun. Oleh karena itu, kegiatan yang melibatkan banyak orang seperti nongkrong, arisan, dan reuni, sebaiknya ditunda terlebih dahulu sampai pandemi COVID-19 ini berakhir. 3). Himbauan untuk selalu menjaga jarak antar sesama. Selalu memperhatikan jarak ketika sedang berinteraksi dengan orang lain minimal satu meter. Karena jika seseorang berada terlalu dekat dengan orang yang terinfeksi virus corona, maka besar kemungkinan seseorang tersebut akan terjangkit juga. 4) Himbauan untuk selalu menghindari kontak fisik atau bersentuhan dengan orang lain. Tangan orang yang terinfeksi bisa saja menjadi tempat menempelnya virus. Oleh karena itu, hendaknya kita berhari-hati selalu ketika bertemu dengan orang lain. Contohnya, ketika ingin berjabat tangan. Selain itu, dianjurkan untuk tidak menyentuk area hidung, mata, dan mulut, arena bisa saja virus berada di tanga tanpa diketahui secara sadar. 5) Himbauan untuk sering mencuci tangan. Semua orang selalu melibatkan tangan untuk hampir semua aktivitanya. Sangat berbahaya jika sewaktu-waktu ada virus yang menempel pada tangan tanpa disadari. Oleh karena itu, kebiasaan memebersihkan tangan dengan mengenakan sabun merupakan bentuk mencegah menempelnya virus corona pada diri seseorang. 6) Himbauan untuk selalu memakai masker. Masker yang digunakan keluar rumah akan sangat bermanfaat dan menghalangi masuknya virus dari orang lain melewati jalur pernapasan. Oleh karena itu, setiap ingin keluar rumah, jangan sampai lupa untuk mengenakan masker.

Keenam pesan itulah yang dapat disampaikan pada kesempatan sosialisasi saat ini. Semua orang diharapkan dapat menjalankannya selama beraktifitas sehari-hari, dan tetap mengikuti arahan pemerintah selama masa pandemi COVID-19 ini demi kenyamanan dan keselamatan semua orang di dunia, khusunya negara ini.

Sampai saat ini, warga terlihat menyambut dengan hangat banner yang telah di pasang di depan desa dan juga ucapan terima kasih dari kepala Desa Urek-urek, Kecamatan Gondanglegi, Kabupaten Malang karena program ini mampu menjadi pengingat bagi warga agar senantiasa berusaha melakukan interaksi yang benar selama pandemi. Program sosialisasi ini dirasakan sebagai langkah strategi kelompok KKN Universitas Negeri Malang dalam upaya ikut serta menjaga negeri pada saat pandemi COVID-19 sekarang ini. Diharapkan juga dengan sosialisasi ini dapat menjadi pemicu bagi masyarakat Desa Urek-urek, Kecamatan Gondanglegi, Kabupaten Malang dalam menjaga kebersihan diri dan lingkungan.

\section{KESIMPULAN}

Hasil dari kegiatan ini dapat dinilai mampu memberikan dampak positif kepada masyarakat Desa Urek-urek, Kecamatan Gondanglegi, Kabupaten Malang, dilihat dari antusias masyarakatnya dalam menerima banner dan video sebagai informasi dan pengingat yang berharga bagi mereka untuk senantiasa menjaga kebersihan selama pandemi. Kerjasama antara kepala desa dan perangkat desa lainnya beserta warganya juga harus ditingkatkan agar selalu menjadi desa yang bersih dan mencegah tersebarnya COVID-19 di negeri ini. 


\section{UCAPAN TERIMA KASIH}

Pada kesempatan ini, mahasiswa KKN Desa Urek-urek menghaturkan terima kasih kepada Lembaga Penelitian dan Pengabdian kepada Masyarakat (LP2M) Universitas Negeri Malang yang melalui kegiatan KKN ini, mendukung dan menunjang adanya kegiatan sosialisasi panduan interaksi selama pandemi COVID-19 dalam rangka mencegah tersebarnya COVID-19 melalui video dan banner di Desa Urek-urek, Kecamatan Gondanglegi, Kabupaten Malang, pada 29 Mei 7 Juli 2020. Ucapan terima kasih juga diucapkan kepada kepala desa dan perangkat desa lainnya yang menerima, memfasilitasi, dan menjadi penghubung mahasiswa KKN dengan masyarakat, sehingga bisa melakukan kegiatan dengan baik. Terimakasih juga dsampaikan kepada Dosen Pembimbing Lapangan (DPL) yang selalu membimbing dan memberi semangat, beserta temanteman anggota KKN Desa Urek-urek atas kerjasama baiknya sehingga program sosialisasi ini dapat berjalan dengan baik serta sesuai dengan harapan.

\section{DAFTAR PUSTAKA}

CDC. (2020, May 13). Symptoms of Coronavirus. CDC, p. 317142. Retrieved from https://www.cdc.gov/coronavirus/2019-ncov/symptoms-testing/symptoms.html

Chen, N., Zhou, M., Dong, X., Qu, J., Gong, F., Han, Y., ... Zhang, L. (2020). Epidemiological and clinical characterisics of 99 cases of 2019 novel coronavirus pneumonia in Wuhan, China: a descriptive study. (January).

Fresia, S. (2017). Efektivitas Pemberian Edukasi Berbasis Audiovisual dan Tutorial Tentang Antiretroviral (ARV) Terhadap Kepatuhan Pengobatan pada Pasien HIV/AIDS di Klinik. The Indonesian Journal of Infectious Disease, 38-45. Retrieved from http://ijidrspisuliantisaroso.co.id/index.php/ijid/article/view/35

Huang, C., Wang, Y., Li, X., Ren, L., Zhao, J., Hu, Y., ... Cao†, B. (2020). Clinical features of patients infected with 2019 novel coronavirus in Wuhan, China. (January).

Hui, D. S. et al. (2020). The continuing 2019-nCoV epidemic threat of novel coronaviruses to global health - The latest 2019 novel coronavirus outbreak in Wuhan, China. (January).

Lai, C., Shih, T., Ko, W., Tang, H., \& Hsueh, P. (2020). Severe acute respiratory syndrome coronavirus 2 (SARS-CoV-2) and coronavirus disease-2019 (COVID-19): The epidemic and the challenges. (January).

Meidiana, R., Simbolon, D., \& Wahyudi, A. (2018). Pengaruh Edukasi melalui Media Audio Visual terhadap Pengetahuan dan Sikap Remaja Overweight. Jurnal Kesehatan, 9(3), 478. https://doi.org/10.26630/jk.v9i3.961

Nugroho, R. S. (2020, March 12). Apa Itu Pandemi Global seperti yang Dinyatakan WHO pada Covid-19? Kompas.Com, pp. 1-2. Retrieved from https://www.kompas.com/tren/read/2020/03/12/060100465/apa-itu-pandemi-globalseperti-yang-dinyatakan-who-pada-covid-19?page $=1$

Sebayang, R. (2020, March 12). Alert! WHO Resmi Tetapkan Corona Pandemi. CNBC Indonesia, p. 1. Retrieved from https://www.cnbcindonesia.com/news/20200312064200-4144245/alert-who-resmi-tetapkan-corona-pandemi

Sekti, R. M., Fayasari, A., Binawan, U., \& Timur, J. (2019). Edukasi Gizi dengan Media Audiovisual terhadap Pola Konsumsi Sayur Buah pada Remaja SMP di Jakarta Timur. 1(2), 77-88.

UNICEF. (2020). Frequently asked questions about coronavirus disease (COVID-19). UNICEF Indonesia, pp. 1-12. Retrieved from https://www.unicef.org/indonesia/coronavirus/FAQ\#whatiscoronavirus

Velavan, T. P., \& Meyer, C. G. (2020). The COVID-19 epidemic. 25(3), 278-280. https://doi.org/10.1111/tmi.13383

Wardhana, D. (2020). Kajian Kebijakan dan Arah Riset Pasca-Covid-19. Jurnal Perencanaan Pembangunan: The Indonesian Journal of Development Planning, 4(2), 223-239. https://doi.org/10.36574/jpp.v4i2.110

World Health Organization, W. (2020a). Pertanyaan dan Jawaban Terkait Coronavirus Disease 2019 (COVID-19). 2019, 1-13. 
World Health Organization, W. (2020b). WHO Director-General's opening remarks at the media briefing on COVID-19. WHO Director General's Speeches, (March), 4. Retrieved from https://www.who.int/dg/speeches/detail/who-director-general-s-opening-remarks-atthe-media-briefing-on-covid-19---11-march-2020 